\title{
Skeletogenesis during the late embryonic development of the catshark Scyliorhinus canicula (Chondrichthyes; Neoselachii)
}

\author{
Enault Sébastien ${ }^{1}$, Adnet Sylvain ${ }^{1}$, Debiais-Thibaud Mélanie ${ }^{1 *}$ \\ ${ }^{1}$ Institut des Sciences de l'Evolution de Montpellier, UMR5554, Université Montpellier, CNRS, IRD, EPHE, c.c.064, place Eugène Bataillon, \\ 34095 Montpellier Cedex 05, France \\ *Corresponding author: melanie.debiais-thibaud@umontpellier.fr
}

\begin{abstract}
Current knowledge on the skeletogenesis of Chondrichthyes is scarce compared with their extant sister group, the bony fishes. Most of the previously described developmental tables in Chondrichthyes have focused on embryonic external morphology only. Due to its small body size and relative simplicity to raise eggs in laboratory conditions, the small-spotted catshark Scyliorhinus canicula has emerged as a reference species to describe developmental mechanisms in the Chondrichthyes lineage. Here we investigate the dynamic of mineralization in a set of six embryonic specimens using X-ray microtomography and describe the developing units of both the dermal skeleton (teeth and dermal scales) and endoskeleton (vertebral axis). This preliminary data on skeletogenesis in the catshark sets the first bases to a more complete investigation of the skeletal developmental in Chondrichthyes. It should provide comparison points with data known in osteichthyans and could thus be used in the broader context of gnathostome skeletal evolution.
\end{abstract}

Keywords: Chondrichthyes, development, mineralization, Scyliorhinus canicula, skeleton

Submitted:2015-10-28, published online:2016-04-25. doi: 10.18563/m3.1.4.e2

\section{INTRODUCTION}

Due to their complex reproductive biology and to the difficulty to raise most species in laboratory conditions, developmental data on Chondrichthyes (sharks, skates, rays and chimaeras) remain scarce when compared with osteichthyans. Among the handful of species currently being used for developmental studies, the small spotted catshark Scyliorhinus canicula (Linnaeus, 1758) is being considered an easy model organism to describe developmental mechanisms in the Chondrichthyes lineage due to its small size and reproductive behavior (Godard and Mazan, 2012). The current reference work on the catshark embryology was done by Ballard et al. (1993), who defined 34 successive stages of embryonic development in the catshark, through description of their observable morphology and anatomy in living embryos. However, this description did not address the development of the cartilaginous skeleton. Most of our current knowledge on chondrichthyan skeletogenesis is therefore based on 19th and 20th century morphological descriptions and is usually based on an admixture of several species and mostly focusing on the skull (e.g. de Beer, 1931; Holmgren, 1940; Gegenbaur, 1872) or vertebrae (Hasse, 1879, 1882a, 1882b). The current renewal in comparative developmental approaches in evolutionary biology led to recent studies of skeletogenesis in Chondrichthyes mostly focusing on molecular aspects of skeletal development (Dahn et al., 2007; Eames et al., 2007; Compagnucci et al., 2013;
D'Souza et al., 2013; Enault et al., 2015; O'Shaughnessy et al., 2015). These studies highlight the necessity for a more global and extensive description of the skeletal development from a morphological perspective in order to better contextualize the description of gene expression patterns. Here we investigate the steps of skeletal mineralization during the embryonic development in the small-spotted catshark using X-ray microtomography. We describe successive stages of skeletal development in six embryos ranging from six centimeters long to ten centimeters long, which roughly corresponds to hatching size. This period in embryonic development correspond to stages 32/34 in Ballard et al. (1993) and lasts about half of the total time of embryogenesis (5-11 months depending on temperature (Ellis and Shackley, 1997)). As we lack a more precise morphological description to be used as a reference time-table within this developmental period, we chose to determine each specimen by its total length. Our data focus on the steps of mineralization of the dermal skeleton (teeth and dermal denticles) and of the axial skeleton (endoskeleton) as detected through $\mathrm{X}$-ray microtomography in the catshark.

\section{METHODS}

Embryos used for this study were obtained at the Station Marine de l'Environnement Littoral (OSU-OREME, Sète, France) and were laid by females from a Mediterranean population fished in central Gulf of Lion (N43 $-43^{\circ} .30^{\prime} \mathrm{E} 4^{\circ}$ - 


\begin{abstract}
Model IDs
M3\#50_SC6_2_2015_03_20

M3\#51_SC6_7_2015_03_20

M3\#52_SC7_1_2015_04_03

M3\#53_SC7_5_2015_03_13

M3\#54_SC8_2015_03_20

M3\#55_SC10_2015_02_27

$\left.4^{\circ} .30^{\prime}\right)$. Eggs were raised in the lab at $18^{\circ} \mathrm{C}$ until proper developmental stages were reached. Embryos were euthanized by overdose of tricaine, and fixed in para-formaldehyde $4 \%$ in buffered phosphate solution, and stored dehydrated in $100 \%$ ethanol. Specimens were rehydrated in buffered phosphate solution before scanning. Scanned specimens were first visualized using AVIZO 6.3 (Visualization Sciences Group Inc., Burlington, MA, USA). All specimens were scanned using the same protocol. The resulting CT projections were processed with the software NRECON using the same reconstruction parameters for all specimens in order to obtain stacks of virtual slices. These images were then processed with AVIZO in order to produce Iso-surface models. Surfaces were then colored in MeshLab (Cignoni et al., 2008) v1.3.3, associated to a position file (.pos) obtained with ISEMeshTools (Lebrun, 2014) and all files share a single tag file linking colors to common anatomical descriptions (see Table 1). Terminology for morphological structures mostly follows Compagno, 1999.
\end{abstract}

Taxon

Scyliorhinus canicula

Scyliorhinus canicula

Scyliorhinus canicula

Scyliorhinus canicula

Scyliorhinus canicula

Scyliorhinus canicula
Short description

Mineralized skeleton of a 6,2 cm long embryo

Mineralized skeleton of a 6,7 cm long embryo

Mineralized skeleton of a 7,1 cm long embryo

Mineralized skeleton of a 7,5 cm long embryo

Mineralized skeleton of a $8 \mathrm{~cm}$ long embryo

Mineralized skeleton of a $10 \mathrm{~cm}$ long embryo

Table 1. List of models

\section{RESULTS}

\section{Dermal denticles}

\section{Primary caudal scales (PCS).}

The primary caudal scales are the first to appear during the catshark embryonic development, and this occurs prior to the stages investigated here (Mellinger and Wrisez, 1993; Debiais-Thibaud et al., 2011). They form two bilateral rows on each side of the tip of the caudal fin. In the first stage investigated, the dorsal and ventral rows all display three small scales which look fused between the right and left side (see Fig. 1A and corresponding3D model). In the $6.7 \mathrm{~cm}$ embryo (see Fig. 1B and corresponding3D model), the dorsal rows display 10 scales each while the ventral rows have 8 scales each, a situation which is supposed to be maintained in all older specimens although some scale are missing in our specimens (see Fig. 1C-F and corresponding 3D models). The primary caudal scales exhibit a rounded circular crown surface, a peduncle smaller than the overlying crown and an overall radial symmetry, though details are difficult to make out due to the size and resolution of the $3 \mathrm{D}$ reconstructions. They develop following a posterior-anterior axis and are completely lost soon after hatching (Mellinger and Wrisez, 1993).

\section{Primary dorsal scales (PDS).}

The small-spotted catshark embryos exhibit two rows of large dermal denticles on the dorsal surface, starting after the last gill slit and ending before the first dorsal fin (Mellinger and Wrisez, 1993). The two rows of PDS are symmetrical: they exhibit the same number of scales on each side. There appears to be intra-population variation in their number: between 27 and 31 PDS per row depending on the embryo. In the first stages studied here, they display a flat and narrow crown, which is lengthened following an anterior-posterior axis (Fig. $1 \mathrm{~A}-\mathrm{C})$. In the later stages investigated, their morphology is more complex, the flat crown has straightened resulting in the cusped appearance of the denticle crown, and they exhibit a broad, radiating peduncle (Fig. 1D-F and see corresponding 3D models for better details). Change in the morphology of the PDS is probably linked to the timing of their eruption and the process of calcification.

\section{Body-covering dermal denticles.}

In addition to the PDS and PCS the small-spotted catshark is covered in minute placoid scales which form a rather homogeneous body covering in the adult. These dermal denticles appear as small cusps lacking distinctive features, such as ridges and grooves (Cappetta, 2012) which is probably due to the scanning resolution. They are first detected in the $7 \mathrm{~cm}$ embryo (Fig. 2A, arrowhead). These first dermal denticles are seen first in the caudal region, just behind the PDS although there is some overlap. In the $7.5 \mathrm{~cm}$ long embryo, dermal placoid scales cover more areas of the body, most notably the snout (Fig. 2B) where they are known to have a protective role for the ampullae of Lorenzi (Reif, 1985). The last two stages investigated, 8 and $10 \mathrm{~cm}$, exhibit a very similar pattern of squamation, with the dermal placoid scales covering the belly and fin margins in addition to the areas described in younger embryos. At all investigated stages, body dermal scales never exhibit the same morphology as the primary dorsal or caudal 
A
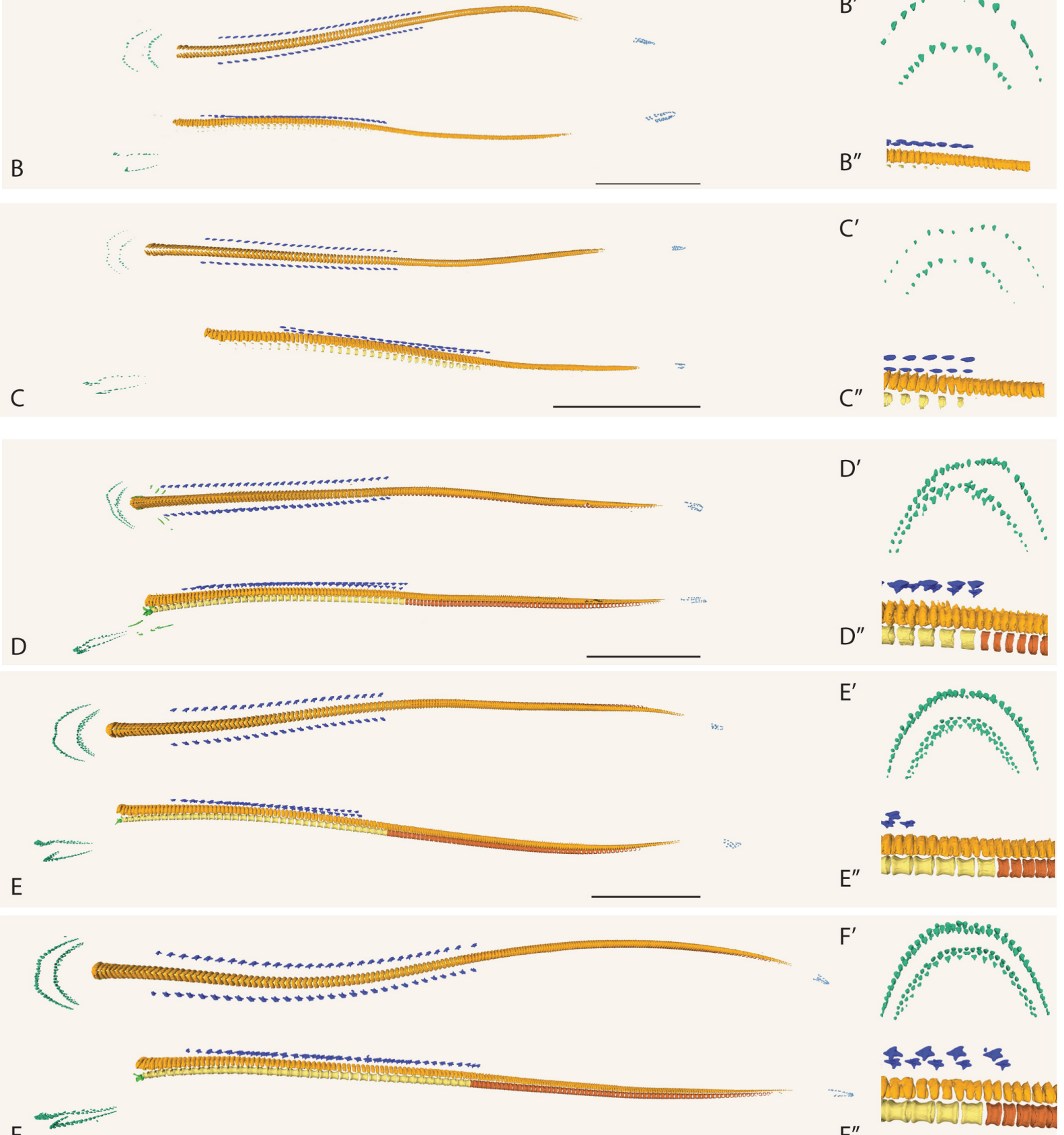

$\mathrm{F}$
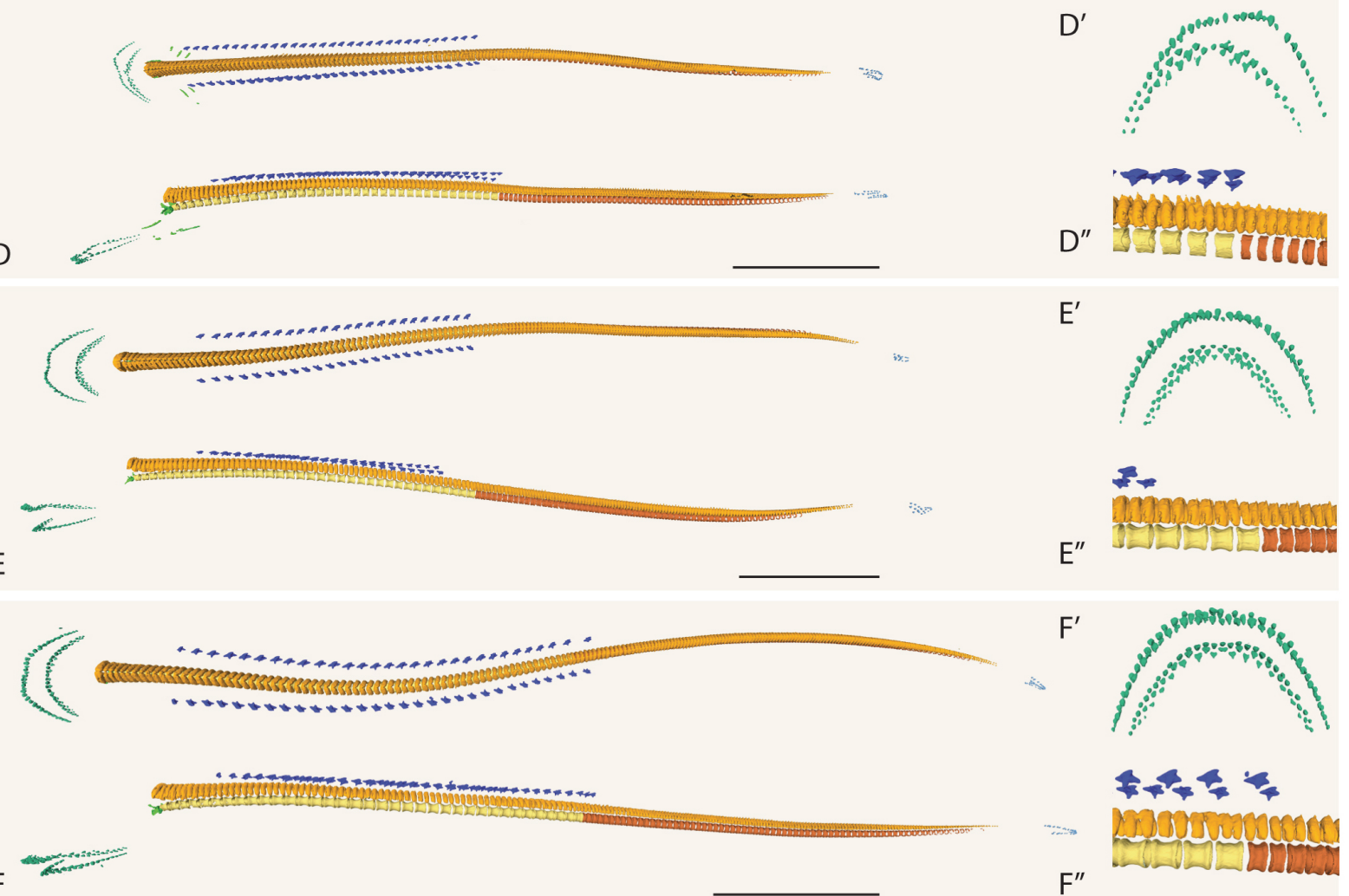

Figure 1. 3D models of the calcified skeleton in Scyliorhinus canicula embryos, dorsal (top) and lateral (bottom) views, surface denticles removed. A: $6.2 \mathrm{~cm}$; B: $6.7 \mathrm{~cm}$; C: $7.1 \mathrm{~cm}$; D: $7.5 \mathrm{~cm}$; E: $8 \mathrm{~cm} ; \mathrm{F}: 10 \mathrm{~cm}$; scale bars: $1 \mathrm{~cm}$. For each specimen, separate panels shows a dorsal close up on the dentition (box with ', dorsal view) and a lateral close up on the developing vertebrae (box with ", lateral view). Color code- light blue: primary caudal scales; deep blue: primary dorsal scales; green: teeth; orange: neural arches; yellow: thoracic vertebral bodies; brown: caudal vertebral bodies. 


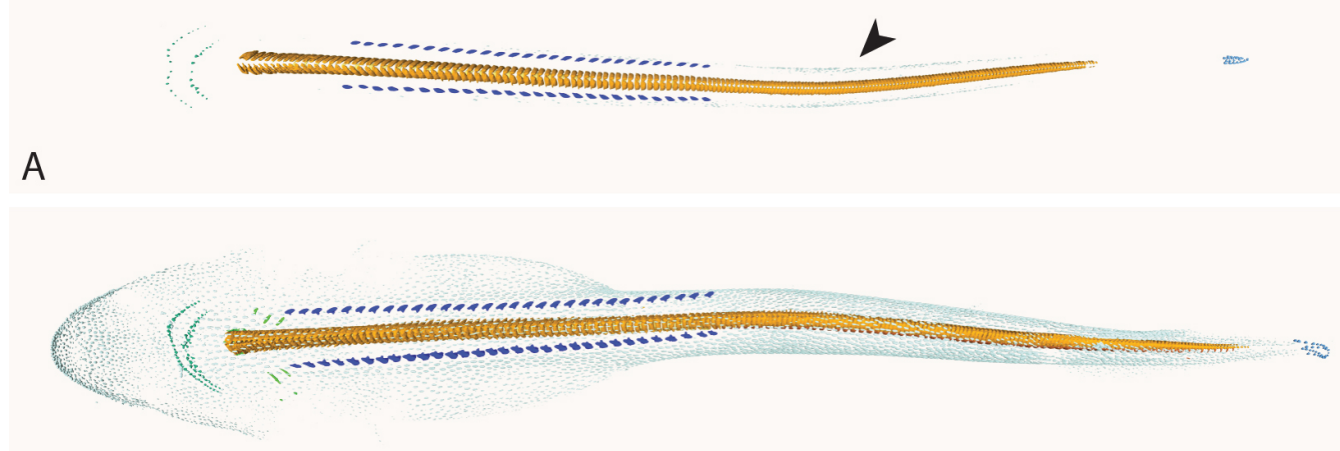

B

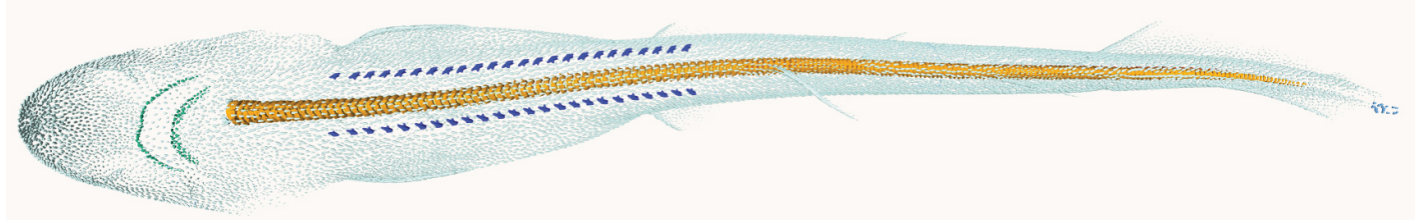

C

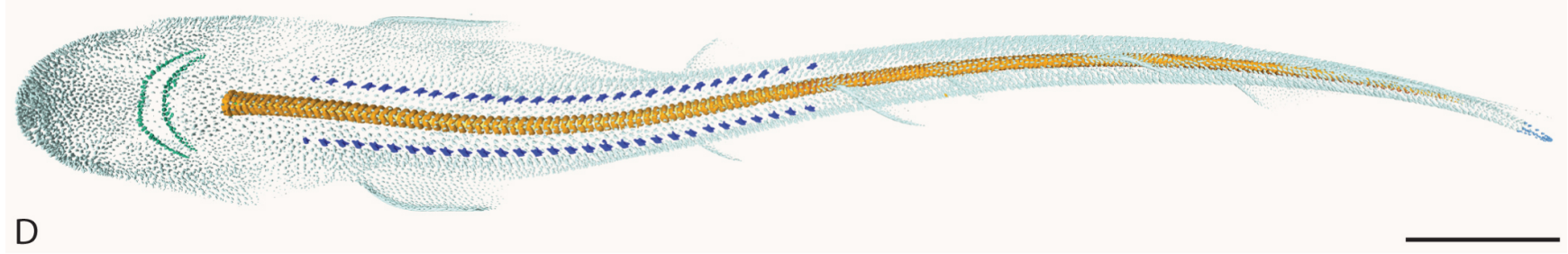

Figure 2. Dorsal view of the embryonic series of Scyliorhinus canicula, including dermal denticles in light green and shown with arrowheads in A (see Figure 1 for color code). A: $7 \mathrm{~cm}$; B: $7.5 \mathrm{~cm}$; C: $8 \mathrm{~cm}$; D: $10 \mathrm{~cm}$; E: $8 \mathrm{~cm}$; F: $10 \mathrm{~cm}$. Scale bar: $1 \mathrm{~cm}$.

scales, as they are formed of a single small cusp.

\section{Teeth}

The first teeth are already mineralized in the $6.2 \mathrm{~cm}$ embryo (also see Reif, 1980; Debiais-Thibaud et al., 2011). They start to develop on the side of the jaws, following a rostrocaudal axis. The symphyseal teeth are not mineralized in the first stage investigated (Fig. 1A'). The symphyseal tooth files appear in the 6.7 and $7 \mathrm{~cm}$ long embryos (Fig. 1B'-C'). In the three first specimens, only a single row of teeth is present, and teeth appear as a single cusp. In the $7.5 \mathrm{~cm}$ embryo, the symphyseal family is fully mineralized and a second row of teeth is added. Teeth are organized in staggered rows, and the accessory cusps are now visible. A third row of teeth is then added in the 8 and $10 \mathrm{~cm}$ embryos investigated here.

\section{Axial skeleton/Vertebral axis}

Vertebrae are not calcified on the first embryo examined (6.2 $\mathrm{cm}$, Fig. 1A). The $6.7 \mathrm{~cm}$ embryo (Fig. 1B, B") exhibits mineralized neural arches, and very poor centrum calcification. Most neural arches appear to be present except for those closest to the tip of the tail $(n=181$ on a total of 205 on the $10 \mathrm{~cm}$ embryo). At $7.1 \mathrm{~cm}$, centrum calcification has started in the thoracic region with 34 vertebral centra detected in the region located between neural arches 3 and 69 (Fig. 1C, C"). The $7.5 \mathrm{~cm}$ embryo presents 37 fully calcified thoracic vertebral centra and 69 partially calcified post-pelvic vertebral centra, with the posteriormost ones being only poorly mineralized (Fig. 1D, D"). The 8 and $10 \mathrm{~cm}$ embryos (Fig. $1 \mathrm{E}-\mathrm{F}, \mathrm{E}$ '-F") exhibit the same pattern of calcification as the $7.5 \mathrm{~cm}$ embryo. At the end of embryonic development $(10 \mathrm{~cm}$ embryo), the last caudal centra and neural arches are still too poorly calcified to be fully detected and reconstructed. At that same stage, vertebral centra and their corresponding neural arches are still not fused together

\section{DISCUSSION}

X-ray microtomography allows for the detection and description of well calcified units of the endo- and dermal skeleton. This work provides preliminary data on the skeletal development in Scyliorhinus canicula and is intended as a first step towards a better description of skeletogenesis in this species. To be able to generalize our observations, we still need to enlarge our sampling and check for intra-specific variations in the absolute and relative timing of mineralization of the differ- 
ent skeletal units. However, this first set of information already highlights a series of important features of skeletal development in the small-spotted catshark. Our results show that calcification of the skeletal system is a progressive process during the embryonic development. Units of the catshark exoskeleton (teeth and dermal scales) calcify through deposition of dentine and enameloid during their development (Reif, 1980). Several sets of dermal scales were previously described to develop at early stages of embryonic development (Mellinger and Wrisez, 1993). The timing of tooth mineralization had also been described previously on histological slides or in toto (Reif, 1980; Debiais-Thibaud et al., 2011) and our results display comparable results, showing that microtomography detection is equivalent in sensitivity for the detection of these highly mineralized, although very small, structures. Our results also allow the description of mineralization patterns in the endoskeleton, although restricted to units of the vertebral axis. With this description, we show that neural arches calcify well before vertebral centra (in individuals of length ranging between 6.2 and $6.7 \mathrm{~cm}$ ) which had also been described in another Scyliorhinidae species (Eames et al., 2007). Calcification of the vertebral centra is first detected in the $7.1 \mathrm{~cm}$ long embryo only. A similar time shift between the calcification of different vertebral units has also been described in most mammals (Hautier et al., 2010). However, calcification of the neural arches may be very low in some Euselachii in their adult form (Compagno, 1988) and, when present, limited to the formation of prismatic cartilage (tesserae) covering the neural arches (Applegate, 1967; Dean and Summers, 2006). In the small-spotted catshark, the calcification of neural arches was shown to occur through the activity of perichondral cells and not through calcification of tesserae within the existing cartilage (Peignoux-Deville et al., 1982; Enault et al., 2015). These data question the representativeness of Scyliorhinidae towards Chondrichthyes regarding the process of neural arch calcification: the description of more neoselachians, especially including batoids species, and holocephalans, will be of first importance to answer this issue. Based on our results, calcification of the vertebral centra in the small-spotted catshark appears to be modular with an early wave of calcification in the thoracic vertebral centra, and a second calcification wave in the post-pelvic centra (see Fig. 1), although we still need a better resolution in embryonic sampling to support this first observation. These two modules correspond to the "monospondylous" and "diplospondylous" vertebrae (Ridewood, 1899; Compagno, 1988). These vertebra groups differ by the size: longer monospondylous centra and smaller diplospondylous centra, which was proposed to be the product of division of one unit into two centra in the diplospondylous region (Ridewood, 1899). Our data do not support this hypothesis as each vertebra centrum starts to ossify as a single unit from the beginning of their development. Note that, in both regions, neural arches are twice more numerous than centra. It seems that these structures will give rise to an alternation of neural arches and interdorsals in adults. Our developmental stages do not allow recognizing which structure will arise from each observed embryonic neural arches. Finally, our descriptions also show that very few units of the endoskeleton are highly calcified in the end of the embryonic period. Neural arches and vertebral centra calcify through specific cell processes that differ from the main calcification process in sharks: the tesserae growth within cartilages (Applegate, 1967; Dean and Summers, 2006). We know from other work that tesserae calcification has barely started in Meckel's cartilage in hatching embryos (Enault et al., 2015), which is not detected in our $10 \mathrm{~cm}$ embryo. Additional descriptions of juveniles by microtomography are therefore necessary to display a more complete picture of skeletal calcification dynamics in the small-spotted catshark. As a conclusion, considering morphological variation of skeletal features within Chondrichthyes (ie poor calcification of deep-sea species (Cappetta, 2012), strong calcification of some bottom-dwelling species (Cappetta, 2012), jaw trabeculation and multiple tesserae layering in some other species (Dingerkus et al., 1991; Summers, 2000; Dean and Summers, 2006), it will be necessary to investigate skeletogenesis in a variety of species (distributed over the group's phylogenetic tree) to i) determine if the patterns described here might be generalized to other Chondrichthyes or rather specific of the Scyliorhinidae; ii) shed possible new light on the interrelationships of Chondrichthyes with other fishes; and iii) determine which skeletal characters could be used in the broader context of gnathostome skeletal evolution. The use of the catshark as a "reference organism" shall not hide the great morphological diversity, and specific derived features, found within Chondrichthyes. We reassert that this skeletal development description in the catshark remains to be completed with additional Chondrichthyes taxa, and we hope further studies will apply to a bigger set of species, in sharks but also in the batoid and the chimeroid lineages.

\section{ACKNOWLEDGEMENTS}

Data presented in this work were produced through the technical facilities of the MRI platform and of the Labex CEMEB. We thank Renaud LEBRUN, Mélanie BURETTE, Mehdi TALEB, Pierre-Antoine VERNET and Marie BUYSSE for their help with data acquisition. We also thank Diego VAZ and Alan PRADEL whose comments greatly helped to improve the quality of this manuscript. Biological materials and breeding tank sets are co-financed by ANR ECODEV $\left(\mathrm{N}^{\circ} 13-\right.$ BSV7-0005) and PEPS ExoMod. This is ISEM publication 2016-078.

\section{BIBLIOGRAPHY}

Applegate, S., 1967. A survey of shark hard parts. In: Gilbert, P., Mathewson, R., Rall, D. (Eds.), Shark, Skates and Rays. The Johns Hopkins Press, Baltimore, Maryland, pp. 37-67.

Ballard, W.W., Mellinger, J., Lechenault, H., 1993. A series of stages for development of Scyliorhinus canicula the lesser spotted dogfish (Chondrichthyes: Scyliorhinidae). Journal of 
Experimental Zoology. 267, 1-43. http://dx.doi.org/10.1002/ jez.1402670309

Cappetta, H., 2012. Handbook of Paleoichthyology, Vol. 3E: Chondrichthyes - Mesozoic and Cenozoic Elasmobranchii: Teeth. Verlag Dr. Friedrich Pfeil.

Cignoni, P., Cignoni, P., Callieri, M., Callieri, M., Corsini, M., Corsini, M., Dellepiane, M., Dellepiane, M., Ganovelli, F., Ganovelli, F., Ranzuglia, G., Ranzuglia, G., 2008. MeshLab: an Open-Source Mesh Processing Tool. Sixth Eurographics Italian Chapter Conference. 129-136.

Compagno, L.J. V., 1988. Sharks of the order Carcharhiniformes. Princeton University Press, New Jersey.

Compagno, L.J. V., 1999. Endoskeleton. In: Hamlett, W.C. (Ed.), Sharks, Skates and Rays. The Biology of Elasmobranch Fishes.

Compagnucci, C., Debiais-Thibaud, M., Coolen, M., Fish, J., Griffin, J.N., Bertocchini, F., Minoux, M., Rijli, F.M., Borday-Birraux, V., Casane, D., Mazan, S., Depew, M.J., 2013. Pattern and polarity in the development and evolution of the gnathostome jaw: both conservation and heterotopy in the branchial arches of the shark, Scyliorhinus canicula. Developmental biology. 377, 428-48. http://dx.doi.org/10. 1016/j.ydbio.2013.02.022

D’Souza, D.G., Rana, K., Milley, K.M., Maclean, H.E., Zajac, J.D., Bell, J., Brenner, S., Venkatesh, B., Richardson, S.J., Danks, J. a, 2013. Expression of Wnt signaling skeletal development genes in the cartilaginous fish, elephant shark (Callorhinchus milii). General and comparative endocrinology. 1-9. http://dx.doi.org/10.1016/j.ygcen.2013.06.021

Dahn, R.D., Davis, M.C., Pappano, W.N., Shubin, N.H., 2007. Sonic hedgehog function in chondrichthyan fins and the evolution of appendage patterning. Nature. 445, 311-314. http://dx.doi.org/10.1038/nature05436

de Beer, G.R., 1931. The development of the skull of Scyllium (Scyliorhinus) canicula L. Quarterly Journal of Microscopical Science. 74, 591-652.

Dean, M.N., Summers, A.P., 2006. Mineralized cartilage in the skeleton of chondrichthyan fishes. Zoology (Jena, Germany). 109, 164-8. http://dx.doi.org/10.1016/j.zool.2006.03. 002

Debiais-Thibaud, M., Oulion, S., Bourrat, F., Laurenti, P., Casane, D., Borday-Birraux, V., 2011. The homology of odontodes in gnathostomes: insights from $D l x$ gene expression in the dogfish, Scyliorhinus canicula. BMC Evolutionary Biology. 11, 307. http://dx.doi.org/10.1186/1471-2148-11307

Dingerkus, G., Seret, B., Guilbert, E., 1991. Multiple prismatic calcium phosphate layers in the jaws of present-day sharks (Chondrichthyes; Selachii). Experientia. 47, 38-40. http://dx.doi.org/10.1007/BF02041246
Eames, B.F., Allen, N., Young, J., Kaplan, A., Helms, J. a, Schneider, R. a, 2007. Skeletogenesis in the swell shark Cephaloscyllium ventriosum. Journal of anatomy. 210, 542-54. http://dx.doi.org/10.1111/j.1469-7580.2007.00723.x

Ellis, J.R., Shackley, S.E., 1997. The reproductive biology of Scyliorhinus canicula in the Bristol Channel, U.K. Journal of Fish Biology. 51, 361-372. http://dx.doi.org/10.1111/j.10958649.1997.tb01672.x

Enault, S., Muñoz, D.N., Silva, W.T.A.F., Borday-birraux, V., Bonade, M., Oulion, S., Ventéo, S., Marcellini, S., DebiaisThibaud, M., 2015. Molecular footprinting of skeletal tissues in the catshark Scyliorhinus canicula and the clawed frog Xenopus tropicalis identifies conserved and derived features of vertebrate calcification. Frontiers in genetics. 6, 1-14. http://dx.doi.org/10.3389/fgene.2015.00283

Gegenbaur, C., 1872. Untersuchungen zur vergleichenden anatomie der wirbelthiere. Drittes heft. Das kopfskelet der selachier, ein beitrag Zur erkenntniss der genese des kopfskelete der wirbelthiere. Leipzig.

Godard, B.G., Mazan, S., 2012. Early patterning in a chondrichthyan model, the small spotted dogfish: towards the gnathostome ancestral state. Journal of anatomy. 222, 56-66. http://dx.doi.org/10.1111/j.1469-7580.2012.01552.x

Hasse, C., 1879. Das natürliche System der Elasmobranchier auf Grundlage des Baues und der Entwicklung ihrer Wirbelsäule. Eine morphologische und paläontologische Studie. I Allgemei, 1-76.

Hasse, C., 1882a. Das natürliche System der Elasmobranchier auf Grundlage des Baues und der Entwicklung ihrer Wirbelsäule. Eine morphologische und paläontologische Studie. II Besonde, 96-179.

Hasse, C., 1882b. Das natürliche System der Elasmobranchier auf Grundlage des Baues und der Entwicklung ihrer Wirbelsäule. Eine morphologische und paläontologische Studie. III, 181-285.

Hautier, L., Weisbecker, V., Sánchez-Villagra, M.R., Goswami, A., Asher, R.J., 2010. Skeletal development in sloths and the evolution of mammalian vertebral patterning. Proceedings of the National Academy of Sciences of the United States of America. 107, 18903-8. http://dx.doi.org/10.1073/pnas .1010335107

Holmgren, N., 1940. Studies of the head in fishes. Part 1. Development of the skull in sharks and rays. Acta Zoologica. 21, 51-257.

Lebrun, R., 2014. ISE-MeshTools, a 3D interactive fossil reconstruction freeware. In: 12th Annual Meeting of EAVP, Torino, Italy.

Mellinger, J., Wrisez, F., 1993. Etude des écailles primaires de l'embryon de la roussette Scyliorhinus canicula (Chondrichthyes: Scyliorhinidae) au microscope électronique à balayage. Annales des Sciences Naturelles, Zoologie, Paris, 13e série. 14, 13-22. 
O’Shaughnessy, K.L., Dahn, R.D., Cohn, M.J., 2015. Molecular development of chondrichthyan claspers and the evolution of copulatory organs. Nature Communications. 6, 6698. http://dx.doi.org/10.1038/ncomms7698

Peignoux-Deville, J., Lallier, F., Vidal, B., 1982. Evidence for the presence of osseous tissue in dogfish vertebrae. Cell and tissue research. 222, 605-614. http://dx.doi.org/10.1007/BF 00213858

Reif, W.-E., 1980. Development of dentition and dermal skeleton in embryonic Scyliorhinus canicula. Journal of morphology. 166, 275-88. http://dx.doi.org/10.1002/jmor .1051660303

Reif, W.-E., 1985. Squamation and ecology of sharks. Cour Forsch Inst Senckenberg. 78, 1-255.

Ridewood, W.G., 1899. Some Observations on the Caudal Diplospondyly of Sharks. Journal of the Linnean Society of London, Zoology. 27, 46-59.

Summers, A., 2000. Stiffening the stingray skeleton- an investigation of durophagy in myliobatid stingrays (Chondrichthyes, batoidea, myliobatidae). Journal of morphology. 243, 113-26. http://dx.doi.org/10.1002/(SICI)10974687(200002)243:2<113::AID-JMOR1>3.0.CO;2-A 